\title{
Editorial
}

\section{Avaliação por período da Ciência e Tecnologia de Alimentos}

Achamos interessante, neste momento no qual tomamos conhecimento do recém publicado Fator de Impacto da Ciência e Tecnologia de Alimentos pela Thomson (ISI-Intitute of Scientific Information/JCR-Journal Citation Report), efetuar uma análise histórica do processo pelo qual a revista vem passando, pois uma nova etapa se inicia e cremos que os olhares e discussões sobre esta publicação devam começar a ter novos critérios.

Quando solicitamos a indexação da Revista, no início de 2005, que convergiu com nosso início na SBCTA, após tantos questionamentos para conhecimento de procedimentos e processo, fomos informados que a revista seria avaliada por dois anos e mais um de procedimentos administrativos. Então seria emitido um parecer de indexação positivo ou negativo. Cumprimos assim os três anos. Desde 2005, toda vez que um fascículo era publicado, imediatamente encaminhávamos o mesmo para a Thomson, juntamente com uma carta explicativa das mudanças efetuadas naquele período de três meses, visto ser a revista trimestral. No início de 2007 recebemos uma correspondência da Thomson nos informando que a partir do primeiro mês de 2007 a revista estava indexada. Então, os artigos já começariam a aparecer no Web of Science, com link para os artigos on line disponibilizados pela SciELO.

Até chegar nesse ponto, empreendemos muitas ações para implantar um novo gerenciamento visando aumentar a qualidade da revista como um todo. Iniciamos pela reorganização administrativa dentro da SBCTA no tocante aos trabalhos relacionados à publicação, como treinamento de funcionários, organização de documentação etc.; contratação de uma empresa que agregasse todo o trabalho de editoração (diagramação, correção gramatical - português, inglês, espanhol -, impressão); posteriormente tivemos que efetuar a troca da empresa para melhoria dos trabalhos, com a implementação dos programas de submissão e de gerenciamento dos artigos. Concomitantemente a isso tudo, íamos administrando os revisores, o corpo editorial, a revisão de todo o trabalho feito pelo pessoal envolvido e, finalmente, o fechamento da revista, com o aprimoramento da qualidade editorial e de impressão. Para otimização de todo esse processo produtivo de difícil controle, a parte gráfica foi agregada à da editoração, agilizando a solução de possíveis conflitos no encaminhamento e impressão da edição já pronta. Não podemos deixar de mencionar todo o trabalho de captura de verba para o pagamento de todo esse sistema. Muitos projetos foram encaminhados às Agências de Fomento (CNPq - CAPES, FAPESP), e em certos momentos verbas da própria Sociedade cobriram algumas lacunas entre os períodos de solicitações. E, diante de tudo, é bom lembrar que a revista é vinculada a uma Sociedade e não pode ter vida própria, estando ligada a um sistema administrativo maior. Bom, com agrados e desagrados, o melhor possível foi feito, e assim temos um fator de impacto ( $\mathrm{FI}=0,267$ ), realçando que nossa porcentagem de autocitação é pequena e que estamos inseridos na área de Ciência e Tecnologia de Alimentos, onde os fatores de impactos são pequenos, variando de 0,086 e 0,088 (Cienc. Tec. Alimentar e Fleischwirtschaft, respectivamente) a 4,356 (Mol. Nutr. Food Res.). Em editoriais sempre foi solicitada a citação dos artigos, pois sabíamos que o número a ser obtido dependeria do quanto a revista e seus artigos fossem valorizados por todos. Infelizmente, nem tudo aconteceu como desejável para começarmos com um número mais alto.

Contudo, se compararmos com revistas brasileiras que já estão indexadas há mais tempo como, por exemplo, Brazilian Journal of Microbiology, com FI = 0,622 na área Microbiologia, Scientia Agrícola, com FI = 0,782 na área Agronomia-Multidisciplinar, reconhecemos que podemos melhorar e, até a próxima avaliação, dar uma alavancada no número atual. Somente para relembrar e chamar a atenção, o Fator de Impacto é definido matematicamente como o número de vezes que os artigos da revista são citados durante um determinado período, dividido pelo número total de artigos publicados por esta revista no mesmo período, convencionado em dois anos.

O cálculo para obtenção do FI da Ciência e Tecnologia de Alimentos foi feito conforme segue:

\begin{tabular}{cccc}
\hline $\begin{array}{c}\text { Citações em 2009 para } \\
\text { artigos publicados em: }\end{array}$ & $\begin{array}{c}\text { Número de artigos } \\
\text { publicados em: }\end{array}$ \\
2008 & 34 & 2008 & 179 \\
2007 & 59 & 2007 & 158 \\
Soma & 93 & Soma & 337 \\
\hline
\end{tabular}

$$
\text { Cálculo }=\frac{\text { Citações recentes em artigos }}{\text { Número de artigos recentes }}=\frac{93}{337}=0,276
$$

Em outras palavras, o cálculo do FI de uma revista leva em conta o número de vezes que os artigos publicados na revista são citados, por ela própria e por outras revistas indexadas, levando-se em consideração o total de artigos publicados no mencionado período de dois anos. As bases de dados processam todas as citações existentes, independente da língua em que o artigo é escrito. Se as citações são antigas, irão alimentar exclusivamente o índice de citação dos autores do artigo, se são recentes, isto é, dos dois últimos anos, servirão a dois propósitos, para o índice de citação dos autores e para o fator de impacto das revistas. A autocitação ou endogenia, isto é, um artigo da revista citando outros artigos da própria revista, é comum e foi um instrumento bastante utilizado para obtenção de fatores de impacto com maior valor por alguns periódicos. Isto é mencionado na contagem das citações, tanto pela SciELO, como pelo ISI, não é bom para o conceito da publicação, contudo não é proibido, 
auxiliando a muitos. O fator de impacto é um instrumento de avaliação de revistas, porém deve ser usado sem muito alarde, conforme a própria Thomson menciona. Os conceitos que devem ser conhecidos pelo editor, como os cientométricos e bibliométricos, auxiliam bastante também na avaliação dos artigos, para que esses sejam editados com melhor qualidade.

Na Ciência e Tecnologia de Alimentos tomamos o cuidado de diminuir o número de artigos regionalizados e converter as submissões somente para o inglês, a fim de elas se tornarem mais atrativas internacionalmente. No entanto, no tocante à grande quantidade de artigos recebidos, tivemos um trabalho adicional que foi a publicação de um grande número de submissões em português neste primeiro período. Ainda não conseguimos verter toda a revista para o inglês.

Seja de forma grandiosa ou de forma apenas trabalhosa e bem intencionada, a Revista da SBCTA continua viva e firmada em uma base sólida, com a garantia básica que a possibilidade de crescimento agrega, apenas dependente de uma valorização que sem dúvida lhe cabe, da parte de uma categoria cada vez mais produtiva e que conta com recursos, graças a governantes que olharam para nossos pesquisadores e vislumbraram um bom futuro e crescimento do país.

Suzana Caetano da Silva Lannes

Editora-chefe 